Article

\title{
Antimicrobial Potential of Essential Oils from Cerrado Plants against Multidrug-Resistant Foodborne Microorganisms
}

\author{
Genilson Silva de Jesus ${ }^{1}$, Ana Camila Micheletti ${ }^{1}$, Rafael Gonçalves Padilha ${ }^{1}{ }^{1}$, \\ Jessica de Souza de Paula ${ }^{1}$, Flavio Macedo Alves ${ }^{2}{ }^{(}$, Cassia Rejane Brito Leal ${ }^{3}{ }^{(0)}$, \\ Fernanda Rodrigues Garcez ${ }^{1}{ }^{\mathbb{D}}$, Walmir Silva Garcez ${ }^{1}$ and Nidia Cristiane Yoshida ${ }^{1, *}$ \\ 1 Institute of Chemistry, Universidade Federal de Mato Grosso do Sul, Av. Senador Filinto Müller 1555, \\ Campo Grande MS 79074460, Brazil; quimicagenilson@gmail.com (G.S.d.J.); \\ anamicheletti@gmail.com (A.C.M.); rafael.gp13@hotmail.com (R.G.P.); \\ depaula.biobach@gmail.com (J.d.S.d.P.); fernandargarcez@gmail.com (F.R.G.); \\ walmir.garcez@ufms.br (W.S.G.) \\ 2 Institute of Biosciences, Universidade Federal de Mato Grosso do Sul, Av. Costa e Silva s/n, \\ Campo Grande MS 79070900, Brazil; flaurace@yahoo.com.br \\ 3 Faculty of Veterinary Medicine and Animal Science, Universidade Federal de Mato Grosso do Sul, Av. \\ Senador Filinto Müller 2443, Campo Grande MS 79070900, Brazil; cassia.leal@ufms.br \\ * Correspondence: nidia.yoshida@ufms.br; Tel.: +55-67-3345-3554
}

Academic Editor: María Amparo Blázquez

Received: 15 May 2020; Accepted: 14 June 2020; Published: 21 July 2020

check for updates

\begin{abstract}
Foodborne pathogens are a real public health concern in an escalating antimicrobial resistance scenario. Natural products represent a promising source of bioactive molecules, and essential oils have attracted much attention due to their myriad of biological properties, including antibacterial activities. In this context, essential oils obtained from the leaves of Chromolaena squalida, Campomanesia sessiliflora, Myrsine guianensis, Matayba guianensis, Siparuna guianensis, Ocotea minarum and Endlicheria paniculata-species from the Cerrado biome of Midwest Brazil-were extracted and evaluated for their antibacterial activity against a panel of four standard and three clinical multidrug-resistant bacterial strains. All tested oils showed moderate to good activity against at least four bacterial strains, including Salmonella Typhi and oxacillin-resistant Staphylococcus. The essential oils from C. squalida, C. sessiliflora, My. guianensis and Ma. guianensis showed strong inhibition of clinical Staphylococcus strains, which cause bovine mastitis and are related to milk-borne diseases. Their chemical profiles were investigated by gas chromatography coupled to mass spectrometry (GC/MS), which revealed a predominance of mono- and sesquiterpene hydrocarbons, some of which with well-known antimicrobial properties. The essential oil from Cerrado plants proved active against resistant Gram-positive and Gram-negative bacteria, revealing their potentialities for the development of new alternative agents to prevent the spreading of resistant bacterial contamination.
\end{abstract}

Keywords: Chromolaena squalida; Myrsine guianensis; Matayba guianensis; Campomanesia sessiliflora; antibacterial; foodborne diseases

\section{Introduction}

Foodborne diseases comprise a large group of illness that result from the consumption of contaminated food or water. The diseases caused by foodborne microorganisms are considered a major concern in global public health, as they can cause significant losses in society and affect the economy, due to treatment, hospitalization and epidemiological investigation costs [1-3]. According to the World Health Organization, the estimated number of cases of foodborne diseases is 600 million 
and 420 thousand deaths each year, which means that 1 in 10 people become ill from consuming contaminated food [2]. Although digestive manifestations are usually mild and self-limited, unsafe foods containing harmful bacteria, viruses, parasites or chemical substances, cause more than 200 diseases-ranging from diarrhea to cancer [2,4].

Several factors favor the increase in foodborne diseases, such as population growth, the need for large-scale food production and changes in eating habits (e.g., increasing the protein intake). The situation is of great concern, mainly due to difficulties in controlling contamination of animals and animal origin products, as they involve multiple factors, such as water, fauna, soil, slaughter and processing practices and storage, among others [5].

The most common foodborne disease worldwide is food poisoning caused by Staphylococcus, considered one of the main pathogens responsible for disease outbreaks related to the consumption of contaminated food [6]. It can be found in several foods, but milk and its derivatives are among the main sources of contamination, since they are good substrates for the growth of different Staphylococcus types and production of enterotoxins [6]. Some studies have shown that these staphylococcal enterotoxins can retain their biological activities even after the pasteurization process $[7,8]$. In addition, this bacterium causes bovine mastitis (inflammation of the mammary gland in the udder of dairy cows), leading to a reduction in milk quality and yield, which causes considerable economic losses in livestock [7]. These economic losses profoundly affect the economy of countries like Brazil, which is an important contributor to the dairy and meat market, as it leads the ranking of countries with the largest cattle herd (214.7 million head) [9] and is the fifth country with the highest milk production [10].

One of the main microorganisms responsible for bovine mastitis is methicillin-resistant Staphylococcus aureus (MRSA). The emergence of multidrug-resistant pathogenic bacteria is a public health concern, as it restricts or extinguishes the availability of the existing antimicrobials [11]. Therefore, it is essential to continuously search for new compounds with antimicrobial activity, especially against multidrug-resistant bacteria, to mitigate this problem [12].

Plant natural products represent an important source of bioactive molecules, since these organisms produce a myriad of complex and structurally diverse chemical compounds, with great pharmacological potentials [12,13]. Essential oils (EOs) are produced by plants and act in the defense against herbivores, and infections caused by microorganisms, as well as attracting pollinators, and in the plant-plant or plant-insect interactions [14,15]. In general, EOs consist of mixtures of 20 to 60 compounds, most of them belonging to the class of terpenoids (mono-, sesqui- and diterpenes) and their oxygenated and aromatic derivatives, in addition to aliphatic acid esters terpenoids and phenolic compounds (usually $\mathrm{C}_{6}-\mathrm{C}_{3}$ derivatives) [16].

In recent years, there has been a growing interest in the potential use of EOs in the food and cosmetics industries. Although EOs are often used in the industry as flavoring agents, these natural products possess a broad range of antimicrobial properties for food preservation. For instance, some EOs, alone or in combination with commercial antibiotics, have shown promising results against multi-resistant bacteria $[17,18]$. In addition, several studies have reported the activity of EOs against pathogens that cause foodborne diseases, suggesting their applications in the food industry [16].

Brazilian flora, enclosed in biomes such as Pantanal and Cerrado, represents one of the highest potentials concerning biological diversity. The Cerrado biome, one of the largest Brazilian ecosystems, covers about $21 \%$ of the Brazilian territory and houses roughly 12,000 species of plants [19], ca. $30 \%$ endemic [20]. However, its extensive degradation and lack of sustainable management, which has been intensified in recent years, have caused severe losses in Cerrado's biodiversity, reinforcing its position as a world hotspot for the conservation of biodiversity, since it presents circa one-third of the biological diversity of Brazil and $5 \%$ of the globe [21,22]. Although several bioactive molecules have been identified from plants of this biome [23], the Cerrado flora still offers a wide biodiversity of species that remains unexplored. Therefore, the Cerrado consists of a promising source of natural products to be investigated regarding their potential for the prevention/treatment of bacterial infections. 
In the face of our rich biodiversity and aiming at finding promising bioactive natural products for food preservation, the present work describes the evaluation of the antimicrobial potential of the essential oils from seven native plants of the Brazilian Cerrado against foodborne diseases-related bacterial stains. In addition, the chemical profile of four of these essential oils with the most promising activity is being described for the first time.

\section{Results}

\subsection{Antimicrobial Screening of Cerrado Plants Essential Oils}

The essential oils from the leaves of seven aromatic plants were obtained by hydrodistillation using a Clevenger-type apparatus, in yields of 0.01 to $0.2 \%$, on a weight basis. The oils were tested against standard strains and clinical isolates of multi-resistant bacteria related to foodborne diseases (Table 1), obtained at the Veterinary Hospital of the Universidade Federal de Mato Grosso do Sul (HV-UFMS).

Table 1. Minimum inhibitory concentration values $\left(\mathrm{MIC}, \mu \mathrm{g} \cdot \mathrm{mL}^{-1}\right.$ ) of the essential oils obtained from the leaves of Chromolaena squalida, Campomanesia sessiliflora, Myrsine guianensis, Matayba guianensis, Siparuna guianensis, Ocotea minarum and Endlicheria paniculata against standard strains of S. aureus, E. coli and P. aeruginosa, and clinical isolated resistant strains *.

\begin{tabular}{|c|c|c|c|c|c|c|c|}
\hline \multirow[b]{2}{*}{$\begin{array}{c}\text { Plant species/ Essential } \\
\text { Oil }\end{array}$} & \multicolumn{7}{|c|}{$\mathrm{MIC}\left(\mu \mathrm{g} \cdot \mathrm{mL}^{-1}\right)$} \\
\hline & $\begin{array}{l}\text { E. coli } \\
\text { NEWP0022 }\end{array}$ & $\begin{array}{c}\text { E. coli } \\
\text { NEWP } \\
0018\end{array}$ & $\begin{array}{c}\text { S. aureus } \\
\text { NEWP } \\
0023\end{array}$ & $\begin{array}{l}\text { P. aeruginosa } \\
\text { NEWP0027 }\end{array}$ & $\begin{array}{l}\text { Staphylococcus sp. } \\
841\end{array}$ & $\begin{array}{l}\text { Staphylococcus sp. } \\
873\end{array}$ & $\begin{array}{l}\text { Salmonella } \\
\text { Typhi } 905\end{array}$ \\
\hline Chromolaena squalida & $>1000$ & $>1000$ & 125 & 500 & 7.80 & 250 & $>1000$ \\
\hline Campomanesia sessiliflora & 500 & $>1000$ & 250 & 500 & 31.25 & 250 & 500 \\
\hline Myrsine guianensis & 500 & $>1000$ & 500 & 500 & 31.25 & 500 & $>1000$ \\
\hline Matayba guianensis & 500 & 500 & 500 & 500 & 125 & 500 & $>1000$ \\
\hline Siparuna guianensis & $>1000$ & $>1000$ & 500 & 500 & 500 & 500 & $>1000$ \\
\hline Ocotea minarum & 500 & $>1000$ & 250 & 500 & 250 & 250 & $>1000$ \\
\hline Endlicheria paniculata & 500 & $>1000$ & 500 & 500 & 500 & 250 & $>1000$ \\
\hline Gentamincin & $\leq 0.5$ & $\leq 0.5$ & $\leq 0.5$ & 3.5 & $\leq 0.5$ & 3.5 & $\leq 0.5$ \\
\hline
\end{tabular}

* Resistance profiles: E. coli NEWP0018: $\beta$-lactamase producer. Coagulase positive Staphylococcus sp. 841: resistant to ampicillin, doxycycline, clindamycin, cefoxitin. Coagulase positive Staphylococcus sp. 873: resistant to ampicillin, doxycycline, clindamycin, penicillin, oxacillin, norfloxacin, cefoxitin, azithromycin. Salmonella Typhi 905: resistant to clindamycin, penicillin, oxacillin.

The EOs of C. squalida, C. sessiliflora and My. guianensis showed good antimicrobial activity against the multi-resistant Staphylococcus sp. 841, isolated from cow's milk with bovine mastitis, with emphasis on C. squalida, which showed the strongest activity (MIC of $7.80 \mu \mathrm{g} \cdot \mathrm{mL}^{-1}$ ). The remaining oils were moderately active against this bacterium. All samples also proved moderately active against Staphylococcus sp. 873, as well as against the standard strains of P. aeruginosa and S. aureus, with MICs ranging from 500 to $125 \mu \mathrm{g} \cdot \mathrm{mL}^{-1}$. Except for C. squalida and S. guianensis, all samples were moderately active against the standard $E$. coli strain. When evaluated against the $\beta$-lactamase producer E. coli and Salmonella Typhi 905 strains, the EOs of Ma. guianensis and C. sessiliflora also showed moderate activity, with an MIC of $500 \mu \mathrm{g} \cdot \mathrm{mL}^{-1}$, while the remaining samples proved inactive against these bacteria.

\subsection{Chemical Profile of the Bioactive Essential Oils}

The chemical composition of the EOs with the best profiles of antimicrobial activity, namely C. squalida, C. sessiliflora, My. guianensis and Ma. guianensis, was analyzed by gas chromatography coupled to mass spectrometry (GC/MS) (Table 2). 
Table 2. Chemical composition of the bioactive essential oils from Cerrado species.

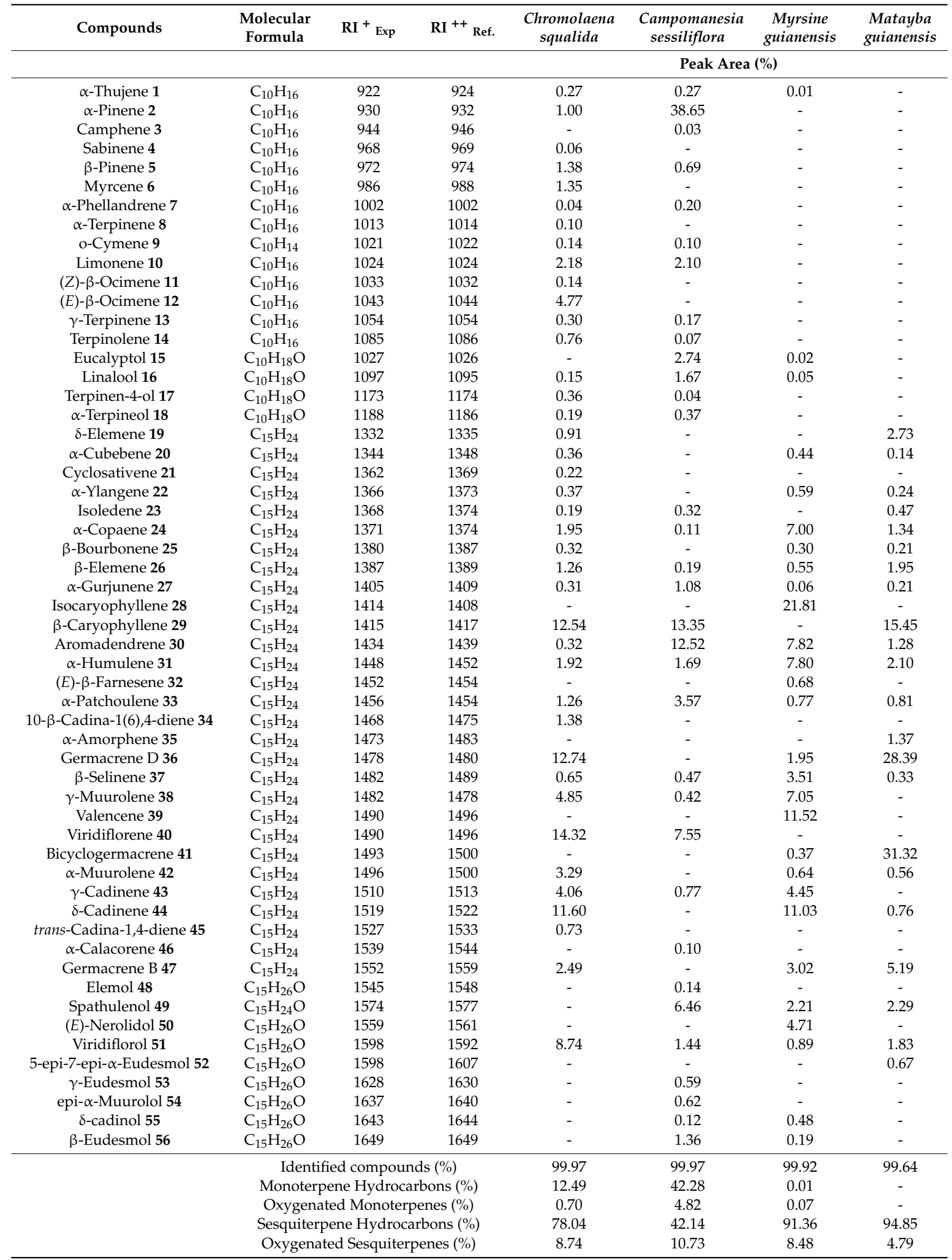

The compounds are listed in order of their elution from the Rtx-MS column. LRI: retention indexes on the Rtx-MS column (relative to n-alkanes $C_{9}-C_{20}$ ). ${ }^{+}$Experimental retention index. ${ }^{++}$Retention index from the literature [24].

The analysis of the EOs obtained from C. squalida and My. guianensis revealed the presence of 40 and 28 components, respectively, mostly of the sesquiterpene-type, and with a predominance of hydrocarbon sesquiterpenes (78.04\% and $91.36 \%$, respectively). Among these compounds, viridiflorene 
(14.32\%), germacrene D (12.74\%), $\beta$-caryophyllene $(12.54 \%)$ and $\delta$-cadinene $(11.60 \%)$ were the principal components of $C$. squalida, while isocaryophyllene (21.81\%) followed by valencene $(11.52 \%)$ and $\delta$-cadinene $(11.03 \%)$ were those of My. guianensis.

Twenty-two compounds were identified in the essential oil from the leaves of Ma. guianensis, which was shown to be composed almost exclusively of hydrocarbon sesquiterpenes (94.85\%), such as bicyclogermacrene $(31.32 \%)$, germacrene $\mathrm{D}(28.39 \%), \beta$-caryophyllene $(15.45 \%)$ and germacrene B (5.19\%).

The EO of C. sessiflora, on the other hand, showed similar contents of mono- and sesquiterpenes (roughly $42 \%$ of each class), in which $\alpha$-pinene was the predominant monoterpene $(38.65 \%)$, while $\beta$-caryophyllene $(13.35 \%)$ and aromadendrene $(12.52 \%)$ were the main sesquiterpene-type components.

\section{Discussion}

Chromolaena squalida, Campomanesia sessiliflora, Myrsine guianensis, Matayba guianensis, Siparuna guianensis, Ocotea minarum and Endlicheria paniculata were selected for the screening of antimicrobial activity based on the criteria of large distribution/occurrence in the Cerrado biome, as well as organoleptic characteristics, focusing on plants with leaves that, when crushed, give off a remarkable fragrance. The species selected in the present study are representatives of the families Asteraceae, Myrtaceae, Primulaceae, Sapindaceae, Siparunaceae and Lauraceae.

Several bacteria are related to foodborne diseases, such as the commensal S. aureus and E. coli, diarrheagenic E. coli, other Staphylococcus species, Clostridium botulinum, Salmonella enterica, Shigella spp, Campylobacter jejuni and Yersinia enterocolitica, among others [25]. In the present work, standard strains of S. aureus, P. aeruginosa, E. coli and $\beta$-lactamase-producing E. coli were selected, in addition to two clinical isolated coagulase positive Staphylococcus spp. and Salmonella Typhi.

The EOs of C. squalida, C. sessilifora and My. guianensis showed the most potent antimicrobial activity against Staphylococcus sp. 841 resistant to ampicillin, doxycycline and clindamicyn, isolated from milk samples produced by cows affected by mastitis, with MIC values ranging from 7.80 to $31.25 \mu \mathrm{g} \cdot \mathrm{mL}^{-1}$. Among these bioactive EOs, emphasis should be given to that from C. squalida, which strongly inhibited this bacterium with the lowest MIC, whose value is considered a good result even for pure substances [26]. All tested oils were moderately active (MICs 250 to $500 \mu \mathrm{g} \cdot \mathrm{mL}^{-1}$ ) against Staphylococcus sp. 873, also isolated from milk, however showing a larger resistance profile (penicillins, including oxacillin, tetracyclines, lincosamides, quinolones, macrolides and second generation cephalosporines), as well as against the standard strain of S. aureus (MICs 125 to $500 \mu \mathrm{g} \cdot \mathrm{mL}^{-1}$ ).

Staphylococcus aureus is an important causative agent of bovine mastitis, which is one of the most cost-intensive diseases in the dairy industry [27]. Furthermore, enterotoxigenic S. aureus strains have the potential to induce foodborne intoxications in humans transmitted by dairy products. A recent study evaluated over a thousand milk samples and revealed that $S$. aureus can effectively enter the dairy production chain via contaminated milk with subclinical S. aureus intramammary infections [28]. Outbreaks caused by staphylococci have been reported all over the word, from both developed and developing countries, such as USA, United Kingdom, France, Austria, Japan, China, Taiwan, Korea, Brazil and Argentina, among others [6,29], reinforcing the difficulty in containment and treating this pathogen.

It is notable that, regarding the chemical composition, the main components of the four EOs analyzed are mostly non oxygenated mono- and sesquiterpenes. In addition, the major components of C. squalida oil, with the best activity profile, are also present in the other EOs, however, in different proportions. The synergistic effect of these components in variable concentrations might therefore be overwhelming. Antimicrobial activity against Staphylococcus aureus and Candida guilliermondii was also reported for EOs rich in compounds similar to those found in C. squalida, such as EO from the leaves of Duguetia gardneriana (Annonaceae), with germacrene D (28.1\%), viridiflorene $(24.0 \%), \beta$-pinene $(12.6 \%)$, $\alpha$-pinene $(9.1 \%)$ and $\beta$-caryophyllene (5.6\%) as its main constituents [30]. $\beta$-Caryophyllene, one of 
the main compounds in C. squalida oil, proved active against Streptococcus mutans [31], Staphylococcus aureus [32] and Helicobacter pylori [33]. Pieri et al. (2016) [34] evaluated $\beta$-caryophyllene against 32 microorganisms linked to bacterial dental plaque formation in dogs, of which, 24 were sensitive to this sesquiterpene at concentrations up to $100 \mathrm{mg} \cdot \mathrm{mL}^{-1}$.

Evaluated against Gram-negative bacteria, which tend to be more resistant to antimicrobial agents than Gram-positive bacteria because of the additional protection afforded by the outer membrane [35], all EOs showed moderate activity against P. aeruginosa and E. coli (standard strain) (MICs $500 \mu g \cdot \mathrm{mL}^{-1}$ ), except for C. squalida and S. guianensis, which proved inactive against the latter.

It is worth mentioning that only Ma. guianensis EO showed activity against $\beta$-lactamaseproducing E. coli, with an MIC of $500 \mu \mathrm{g} \cdot \mathrm{mL}^{-1}$. The composition of this EO is characterized by the presence of sesquiterpenes, with no trace of monoterpenoids, of which $31.32 \%$ consist of bicyclogermacrene. This main component was previously reported as active against P. aeruginosa, Acinetobacter baumanii and E. coli [36].

The EO of C. sessiliflora was the only sample active against Salmonella Typhi 905, resistant to clindamicyn, penicillin and oxacillin, with an MIC of $500 \mu \mathrm{g} \cdot \mathrm{mL}^{-1}$. A particular feature in the chemical profile of this EO was the presence of the monoterpene $\alpha$-pinene as its major component (38.65\% of the total oil composition). This monoterpene is listed by the US Food and Drug Administration among the food additives permitted for direct addition to food for human consumption, and also has been considered as a potentially useful natural antibacterial preservative as an alternative for $\mathrm{SO}_{2}$ in winemaking [37].

Although the antimicrobial effects and chemical composition of the plants evaluated in the present study have not been previously investigated, species belonging to the same genera as those investigated herein are known to exhibit antimicrobial properties. The EOs from flowers and fruits of Chromolaena laevigata were investigated for their chemical composition and antimicrobial activity, showing an MIC of $62.5 \mathrm{mg} \cdot \mathrm{mL}^{-1}$ against Candida albicans and $S$. aureus, and an MIC of $500 \mathrm{mg} \cdot \mathrm{mL}^{-1}$ against $P$. aeruginosa [38]. The EO from the leaves of Campomanesia adamantium showed high activity against $S$. aureus, P. aeruginosa and C. albicans and was moderately active against E. coli, and its main compounds were found to be monoterpenes, such as limonene, $\alpha$-pinene and $\beta$-pinene [39]. The EO extracted from the leaves of Campomanesia guazumifolia (Cambess.) O. Berg strongly inhibited the strains of S. aureus $\left(\mathrm{MIC} 15 \pm 0.1 \mu \mathrm{g} \cdot \mathrm{mL}^{-1}\right)$, E. coli (MIC $25 \pm 0.2 \mu \mathrm{g} \cdot \mathrm{mL}^{-1}$ ) and C. albicans (MIC $\left.5 \pm 0.1 \mu \mathrm{g} \cdot \mathrm{mL}^{-1}\right)$. Sixty-eight compounds were identified in its oil, of which the main constituents were bicyclogermacrene $(15 \%)$, globulol (5\%) and spathulenol (5\%) [40].

The use of leaves as a source of EOs warrants the sustainable use of these plants. This fact deserves to be highlighted, since such plants have popular/medicinal uses. The decoction of leaves of Chromolaena squalida, popularly known as cambará-roxa, mata-pasto, casadinha or erva-de-são-miguel [41], is used in folk medicine to treat cough and as an antipyretic [42]. The species Campomanesia sessiliflora, popularly known as guabiroba-verde, is frequently found in the Brazilian Cerrado [43] and produces edible fruits, consumed in natura by the local population. Matayba guianensis, known as brazeiro, camboatá, camboatã, camboatá-branco, olho-de-cotia, mataíba, batabaíba, cuvantã, jatuá-uba, jatuá-iba, pau-da-digestão, atou-aou, tou-aou or canela-de-negro [44], is considered a medicinal plant, and infusions and decocts of its root are used in the treatment of respiratory diseases and to alleviate back and leg pain [45]. The plant Mysrine guianensis, popularly known as caapororoca, capororoca and pororoca [46], is used in folk medicine as an antiseptic [47] and antiparasitic [48].

Food safety can be considered as a priority, since foodborne diseases have emerged as a serious public health problem, besides leading to huge economic and social losses worldwide, especially in low- and middle-income countries. Our results reveal a promising activity of EOs from Cerrado plants against foodborne bacteria, revealing their potentialities for the development of new agents to prevent the spreading of resistant bacterial contamination in the food production chain, contributing to reduce the risks of foodborne diseases. Further toxicological studies are required for safety purposes. 


\section{Materials and Methods}

Plant Material. The leaves of the species Chromolaena squalida (DC.) R.M. King \& H. Rob. (Asteraceae), Campomanesia sessiliflora (O. Berg) Mattos (Myrtaceae), Matayba guianensis Aubl. (Sapindaceae), Myrsine guianensis (Aubl.) Kuntze (Primulaceae), Siparuna guianensis A. DC. (Siparunaceae), Ocotea minarum (Nees \& Mart.) Mez (Lauraceae) and Endlicheria paniculata (Spreng.) J.F. Macbr. (Lauraceae) were collected in March 2020, at Campo Grande, Mato Grosso do Sul, Brasil $\left(20^{\circ} 30^{\prime} 29^{\prime \prime} \mathrm{S}\right.$ and $\left.54^{\circ} 36^{\prime} 58^{\prime \prime} \mathrm{W}\right)$. The botanical identification of the species was carried out by Dr. Flávio M. Alves (UFMS), and all exsiccates (deposit number are 2040, 37574, 74331, 74300, 74339, 74374, 72774, respectively) were deposited at the CGMS Herbarium (UFMS). License for research on Brazil's biodiversity, \#A1D8864.

Essential oil extraction. Fresh leaves of C. squalida (526 g), C. sessiliflora (486 g), Ma. guianensis (576 g), My. guianensis (483 g), S. guianensis (487 g), O. minarum (500 g) and E. paniculata (424 g) were separately subjected to hydrodistillation in a Clevenger-type apparatus for $8 \mathrm{~h}$, to yield $280 \mathrm{mg}(0.05 \%$ $w / w), 916 \mathrm{mg}(0.19 \% \mathrm{w} / w), 1.2 \mathrm{~g}(0.2 \% \mathrm{w} / w), 76 \mathrm{mg}(0.015 \% \mathrm{w} / \mathrm{w}), 2.6 \mathrm{~g}(0.5 \% \mathrm{w} / \mathrm{w}), 690 \mathrm{mg}(0.14 \% \mathrm{w} / w)$ and $544 \mathrm{mg}(0.13 \% \mathrm{w} / \mathrm{w})$ of essential oils, respectively.

Gas chromatography/mass spectrometry (GC/MS). The GC/MS analysis was performed using a Shimadzu GC/MS QP-2010 PLUS Gas Chromatograph coupled to a mass spectrometer operating at $70 \mathrm{eV}$ and an Rtx-MS column (Restek ${ }^{\circledR}$, Bellefonte, PA, USA) (30 m ×0.25 mm ×0.25 pm) consisting of 5\%-diphenyl-95\%-dimethylpolysiloxane.

Chromatography conditions. Injector temperature was $250{ }^{\circ} \mathrm{C}$, with the carrier gas (helium) at a flow rate of $1 \mathrm{~mL} \cdot \mathrm{min}^{-1}$, pressure of $87.1 \mathrm{kPa}$ and column oven temperature programmed to $50-260{ }^{\circ} \mathrm{C}\left(3^{\circ} \mathrm{C} / \mathrm{min}\right)$. A mixture of linear hydrocarbons (C9 to $\mathrm{C} 22$ alkanes) was injected under the same experimental conditions. The identification of the constituents in the essential oil was performed by comparing the mass spectra obtained with those of the equipment database (Wiley 7 lib and Nist 08 lib) and by using the retention index (RI), calculated for each constituent as previously described [24].

Antimicrobial assays. All reagents and media for the antibacterial assays were purchased from Sigma Aldrich ${ }^{\mathrm{TM}}$. The standard bacterial strains used were S. aureus (NEWP0023), E. coli (NEWP0022), E. coli (NEWP0018, $\beta$-lactamase producer) and P. aeruginosa (NEWP0027). Veterinary clinical strains Staphylococcus sp. 841(resistant to ampicillin, doxycycline, clindamicyn, cefoxitin), Staphylococcus sp. 873 (resistant to ampicilin, doxycycline, clindamicyn, penicillin, oxacillin, norfloxacin, cefoxitin, azithromycin) and Salmonella Typhi 905 (resistant to clindamicyn, penicillin, oxacillin) were provided by the Veterinary Hospital, Faculty of Veterinary Medicine and Animal Science of Universidade Federal de Mato Grosso do Sul (Campo Grande, Brazil). License of the bacterial collection for research on Brazil's biodiversity, \#C69392D.

The antimicrobial activity of the essential oils was determined by the broth microdilution method, as described by Manda et al. (2018) [49]. Two-fold dilutions were performed in 96-well plates prepared with Mueller-Hinton broth to reach a final concentration of 1.95 to $4000 \mu \mathrm{g} \cdot \mathrm{mL}^{-1}$, with a $100 \mu \mathrm{L}$ final volume in each well. The inoculums were overnight cultures of each bacterial species in Mueller-Hinton agar diluted in sterile saline solution $(0.45 \%)$ to a concentration of approximately $10^{8} \mathrm{CFU} \cdot \mathrm{mL}^{-1}$. This solution was diluted $1 / 10$ in saline solution $(0.45 \%)$ and $5 \mu \mathrm{L}$ was added to each well containing the test samples. All experiments were performed in triplicate and the microdilution trays were incubated at $36^{\circ} \mathrm{C}$ for $18 \mathrm{~h}$. Then, $20 \mu \mathrm{L}$ of an aqueous solution $(0.5 \%)$ of triphenyl tetrazolium chloride (TTC) was added to each well and the trays were again incubated at $36{ }^{\circ} \mathrm{C}$ for $2 \mathrm{~h}$. In those wells where bacterial growth did occur, TTC changed from colorless to red. MIC was defined as the lowest concentration of each substance at which no color change occurred and was expressed in $\mu \mathrm{g} \cdot \mathrm{mL}^{-1}$. 
Author Contributions: G.S.d.J., R.G.P. and J.d.S.d.P. performed the extraction of the essential oils, chemical data analysis and contributed to the preparation of the manuscript; A.C.M. performed the antimicrobial assays, data analysis and contributed to the design of the study; A.C.M., F.R.G. and W.S.G. contributed to the writing and review of the manuscript; C.R.B.L. isolated and provided the clinical bacteria strains and antibiograms; F.M.A. collected the plant material; N.C.Y. performed chemical data analysis, wrote the manuscript, was responsible for the conception and design of the study and project administration. All authors have read and agreed to the published version of the manuscript.

Funding: This research was supported by Coordenação de Aperfeiçoamento de Pessoal de Nível Superior (CAPES), grant number 001 and CPq-PROPP-UFMS.

Acknowledgments: The authors are grateful to Coordenação de Aperfeiçoamento de Pessoal de Nível Superior-CAPES (Finance Code 001), and CPq-PROPP-UFMS for their financial support. Thanks are also given to Conselho Nacional de Ciência e Tecnologia-CNPq (G.S.d.J.), CAPES (R.G.P.) and Fundação de Apoio ao Desenvolvimento do Ensino, Ciência e Tecnologia do Estado de Mato Grosso do Sul- FUNDECT-MS (J.d.S.d.P.) for the grants awarded.

Conflicts of Interest: The authors declare no conflict of interest.

\section{References}

1. WHO. WHO Estimates of the Global Burden of Foodborne Diseases: Foodborne Disease Burden Epidemiology Reference Group 2007-2015; World Health Organization, Ed.; WHO: Geneva, Switzerland, 2015; ISBN 978-924-156-516-5.

2. WHO. Strengthening Surveillance of and Response to Foodborne Diseases: A Practical Manual. Introductory Module; World Health Organization, Ed.; WHO: Geneva, Switzerland, 2017; ISBN 978-92-4-151324-1.

3. Jaffee, S.; Henson, S.; Unnevehr, L.; Grace, D.; Cassou, E. The Safe. Food Imperative: Accelerating Progress in Lowand Middle-Income Countries. Agriculture and Food Series; World Bank: Washington, DC, USA, 2019. [CrossRef]

4. WHO. Whole Genome Sequencing for Foodborne Disease Surveillance: Landscape Paper; World Health Organization, Ed.; WHO: Geneva, Switzerland, 2018; ISBN 978-92-4-151386-9.

5. Heredia, N.; García, S. Animals as sources of food-borne pathogens: A Review. Anim. Nutr. 2018, 4, $250-255$. [CrossRef] [PubMed]

6. Dai, J.; Wu, S.; Huang, J.; Wu, Q.; Zhang, F.; Zhang, J.; Wang, J.; Ding, Y.; Zhang, S.; Yang, X.; et al. Prevalence and characterization of Staphylococcus aureus isolated from pasteurized milk in China. Front. Microbiol. 2019, 10, 1-10. [CrossRef] [PubMed]

7. Sugrue, I.; Tobin, C.; Ross, R.P.; Stanton, C.; Hill, C. Foodborne pathogens and zoonotic diseases. In Raw Milk: Balance between Hazards and Benefits, 1st ed.; Nero, L., De Carvalho, A.F., Eds.; Academic Press: Cambridge, MA, USA, 2019; Volume 1, pp. 259-272; ISBN 978-0-12-810530-6.

8. Rall, V.L.M.; Vieira, F.P.; Rall, R.; Vieitis, R.L.; Fernandes, A., Jr.; Candeias, J.M.G.; Cardoso, K.F.G.; Araújo, J.P., Jr. PCR detection of staphylococcal enterotoxin genes in Staphylococcus aureus strains isolated from raw and pasteurized milk. Vet. Microbiol. 2008, 132, 408-413. [CrossRef] [PubMed]

9. Brazilian Beef. Available online: http://www.brazilianbeef.org.br/Summary.aspx (accessed on 9 May 2020).

10. FAO, Food and Agriculture Organization of the United Nations. Dairy Market Review. March 2020. Available online: http://www.fao.org/dairy-production-products/resources/publications/fao-publications/en/ (accessed on 4 May 2020).

11. Magiorakos, A.-P.; Srinivasan, A.; Carey, R.B.; Carmeli, Y.; Falagas, M.E.; Giske, C.G.; Harbarth, S.; Hindler, J.F.; Kahlmeter, G.; Olsson-Liljequist, B.; et al. Multidrug-resistant, extensively drug-resistant and pandrug-resistant bacteria: An international expert proposal for interim standard definitions for acquired resistance. Clin. Microbiol. Infect. 2011, 18, 268-281. [CrossRef] [PubMed]

12. Imane, N.I.; Fouzia, H.; Azzahra, L.F.; Ahmed, E.; Idrissa, D.; Mohamed, K.-H.; Sirine, F.; L'Houcine, O.; Noureddine, B. Chemical composition, antibacterial and antioxidant activities of some essential oils against multidrug resistant bacteria. Eur. J. Integr. Med. 2020, 35, 1-24. [CrossRef]

13. Newman, D.J.; Cragg, G.M. Natural products as sources of new drugs over the nearly four decades from 01/1981 to 09/2019. J. Nat. Prod. 2020, 83, 770-803. [CrossRef]

14. Maffei, M.E.; Gertsch, J.; Appendino, G. Plant volatiles: Production, function and pharmacology. Nat. Prod. Rep. 2011, 28, 1359-1380. [CrossRef]

15. Yoshida, N.C.; Saffran, F.P.; Lima, W.G.; Freire, T.V.; Siqueira, J.M.; Garcez, W.S. Chemical characterization and bioherbicidal potential of the essential oil from the leaves of Unonopsis guatterioides (A.DC.) R.E.Fr. (Annonaceae). Nat. Prod. Res. 2019, 33, 1-5. [CrossRef] 
16. Chouhan, S.; Sharma, K.; Guleiria, S. Antimicrobial activity of some essential oils—Present status and Future perpectives. Medicines 2017, 4, 58. [CrossRef]

17. Solarte, A.L.; Astorga, R.J.; Aguiar, F.; Relaño-Galán, A.; Maldonado, A.; Huerta, B. Combination of antimicrobials and essential oils as an alternative for the control of Salmonella enterica multiresistant strains related to foodborne disease. Foodborne Pathog. Dis. 2017, 14, 1-6. [CrossRef]

18. Lambert, R.J.W.; Skandamis, P.N.; Coote, P.J.; Nychas, G.-J.E. A study of the minimum inhibitory concentration and mode of action of oregano essential oil, thymol and carvacrol. J. Appl. Microbiol. 2001, 91, 453-462. [CrossRef] [PubMed]

19. Strassburg, B.B.; Latawiec, A.; Balmford, A. Brazil: Urgent action on Cerrado extinctions. Nature 2016, 540, 199. [CrossRef] [PubMed]

20. Forzza, R.C.; Baumgratz, J.F.A.; Bicudo, C.E.M.; Canhos, D.A.L.; Carvalho, A.A.; Costa, A.F.; Costa, D.P.; Hopkins, M.; Leitman, P.M.; Lohmann, L.G.; et al. Catálogo de Plantas e Fungos do Brasil, 1st ed.; Andrea Jakobsson Estúdio Editorial: Rio de Janeiro, Brazil, 2010; ISBN 978-85-88742-43-7.

21. Sano, S.M.; Almeida, S.P.; Ribeiro, J.F. Cerrado: Ecologia e Flora, 1st ed.; Embrapa Cerrados: Brasília, Brazil, 2008; ISBN 9788573834215.

22. Strassburg, B.B.N.; Brooks, T.; Feltran-Barbieri, R.; Iribarrem, A.; Crouzeilles, R.; Loyola, R.; Latawiec, A.E.; Filho, F.J.B.O.; Scaramuzza, C.A.M.; Scarano, F.R.; et al. Moment of truth for the Cerrado hotspot. Nat. Ecol. Evol. 2017, 1, 1-3. [CrossRef] [PubMed]

23. Garcez, F.R.; Garcez, W.S.; Yoshida, N.C.; Figueiredo, P.O. A Diversidade dos constituintes químicos da flora de Mato Grosso do Sul e sua relevância como fonte de substâncias bioativas. Rev. Virtual Quim. 2016, 8, 97-126. [CrossRef]

24. Adams, R.P. Identification of Essential Oil Components by Gas. Chromatography/Mass Spectrometry, 4th ed.; Allured Publishing Corporation: Carol Stream, IL, USA, 2007; p. 811; ISBN 978-193-263-321-4.

25. Kirk, M.D.; Pires, S.M.; Black, R.E.; Caipo, M.; Crump, J.A.; Desvleesschauwer, B.; Döpfer, D.; Fazil, A.; Fischer-Walker, C.L.; Hald, T.; et al. World Health Organization Estimates of the Global and Regional Disease Burden of 22 Foodborne Bacterial, Protozoal, and Viral Diseases, 2010: A Data Synthesis. PLoS Med. 2015, 12, 1-21. [CrossRef]

26. Kuete, V. Potential of Cameroonian plants and derived products against microbial infections: A review. Planta. Med. 2010, 76, 1479-1491. [CrossRef] [PubMed]

27. Dufour, S.; Dohoo, I.R.; Barkema, H.W.; Descôteaux, L.; Devries, T.J.; Reyher, K.K.; Roy, J.P.; School, D.T. Manageable risk factors associated with the lactational incidence, elimination, and prevalence of Staphylococcus aureus intramammary infections in dairy cows. J. Dairy Sci. 2012, 95, 1283-1300. [CrossRef]

28. Kümmel, J.; Stessl, B.; Gonano, M.; Walcher, G.; Bereuter, O.; Fricker, M.; Grunert, T.; Wagner, M.; Ehling-Schulz, M. Staphylococcus aureus entrance into the dairy chain: Tracking S. aureus from dairy cow to cheese. Front. Microbiol. 2016, 7, 1-11. [CrossRef]

29. Argudín, M.Á.; Mendoza, M.C.; Rodicio, M.R. Food poisoning and Staphylococcus aureus enterotoxins. Toxins 2010, 2, 1751-1773. [CrossRef]

30. Almeida, J.R.G.S.; Facanali, R.; Vieira, M.A.R.; Marques, M.O.M.; Lúcio, A.S.S.C.; Lima, E.O.; Barbosa-Filho, J.M. Composition and Antimicrobial Activity of the Leaf Essential Oils of Duguetia gardneriana Mart. And Duguetia moricandiana Mart. (Annonaceae). J. Essent. Oil Res. 2010, 22, 275-278. [CrossRef]

31. Yoo, H.J.; Jwa, S.K. Inhibitory effects of $\beta$-caryophyllene on Streptococcus mutans biofilm. Arch. Oral Biol. 2018, 88, 42-46. [CrossRef] [PubMed]

32. Neta, M.C.S.; Vittorazzi, C.; Guimarães, A.C.; Martins, J.D.L.; Fronza, M.; Endringer, D.C.; Scherer, R. Effects of $\beta$-caryophyllene and Murraya paniculata essential oil in the murine hepatoma cells and in the bacteria and fungi 24h time-kill curve studies. Pharm. Biol. 2017, 55, 190-197. [CrossRef] [PubMed]

33. Woo, H.J.; Yang, J.Y.; Lee, M.H.; Kim, H.W.; Kwon, H.J.; Park, M.; Kim, S.K.; Park, S.Y.; Kim, J.B. Inhibitory effects of $\beta$-Caryophyllene on Helicobacter pylori infection in vitro and in vivo. Int. J. Mol. Sci. 2020, $21,1008$. [CrossRef] [PubMed]

34. Pieri, F.A.; Souza, M.C.C.; Vermelho, L.L.R.; Vermelho, M.L.R.; Perciano, P.G.; Vargas, F.S.; Borges, A.P.B.; Veiga-Junior, V.F.; Moreira, M.A.S. Use of $\beta$-caryophyllene to combat bacterial dental plaque formation in dogs. BMC Vet. Res. 2016, 12, 216. [CrossRef]

35. Epand, R.M.; Walker, C.; Epand, R.F.; Magarvey, N.A. Molecular mechanisms of membrane targeting antibiotics. Biochim. Biophys. Acta. 2015, 1858, 980-987. [CrossRef] [PubMed] 
36. Santos, T.G.; Dognini, J.; Begnini, I.M.; Rebelo, R.A.; Verdi, M.; Gasper, A.L.D.; Dalmarco, E.M. Chemical characterization of essential oils from Drimys angustifolia Miers (Winteraceae) and antibacterial activity of their major compounds. J. Braz. Chem. Soc. 2013, 24, 164-170. [CrossRef]

37. Shih, M.-K.; Lai, Y.-H.; Lin, C.-M.; Chen, Y.-W.; Hou, Z.-T.; Hou, C.-Y. A novel application of terpene compound $\alpha$-pinene for alternative use of sulfur dioxide-free white wine. Int. J. Food Prop. 2020, 23, 520-532. [CrossRef]

38. Murakami, C.; Lago, J.H.G.; Perazzo, F.F.; Ferreira, K.S.; Lima, M.E.L.; Moreno, P.R.H.; Young, M.C.M. Chemical Composition and Antimicrobial Activity of Essential Oils from Chromolaena laevigataduring Flowering and Fruiting Stages. Chem. Biodivers. 2013, 10, 621-627. [CrossRef]

39. Coutinho, I.D.; Cardoso, C.A.L.; Ré-Poppi, N.; Melo, A.M.; Vieira, M.C.; Honda, N.K.; Coelho, R.G. Gas Chromatography-Mass Spectrometry (GC-MS) and evaluation of antioxidant and antimicrobial activities of essential oil of Campomanesia adamantium (Cambess.) O. Berg (Guavira). Braz. J. Pharm. Sci. 2009, 45, 767-776. [CrossRef]

40. Santos, A.L.; Polidoro, A.S.; Cardoso, C.A.L.; Batistote, M.; Vieira, M.C.; Jacques, R.A.; Camarão, E.B. GC $\times$ GC/qMS analyses of Campomanesia guazumifolia (Cambess.) O. Berg essential oils and their antioxidant and antimicrobial activity. Nat. Prod. Res. 2017, 33, 1-5. [CrossRef]

41. Durigan, G.; Pilon, N.A.L.; Assis, G.B.; Souza, F.M.; Baitello, J.B. Plantas Pequenas do Cerrado: Biodiversidade Negligenciada, 1st ed.; Secretaria do Meio Ambiente do Estado de São Paulo: São Paulo, Brazil, 2018; p. 720; ISBN 978-85-8156-030-4.

42. Messias, M.C.T.B.; Menegatto, M.F.; Prado, A.C.C.; Santos, B.R.; Guimarães, M.F.M. Uso popular de plantas medicinais e perfil socioeconômico dos usuários: Um estudo em área urbana em Ouro Preto, MG, Brasil. Rev. Bras. Plantas. Med. 2015, 17, 76-104. [CrossRef]

43. Kataoka, V.M.F.; Cardoso, C.A.L. Avaliação do perfil cromatográfico obtidos por CLAE-DAD e da atividade antioxidante das folhas de espécies Campomanesia sessiliflora (O. Berg) Mattos e Campomanesia xanthocarpa O. Berg. Ver. Bras. Plantas Med. 2013, 15, 121-129. [CrossRef]

44. Coelho, R.L.G.; Souza, V.C.; Ferrucci, M.S.; Flores, T.B. Revisão taxonômica de Matayba sect. Matayba (Sapindaceae, Cupanieae). Rodriguésia 2017, 68, 411-443. [CrossRef]

45. Souza, R.K.D.; Silva, M.A.P.; Menezes, I.R.A.; Ribeiro, D.A.; Bezerra, L.R.; Souza, M.M.A. Ethnopharmacology of medicinal plants of carrasco, northeastern Brazil. J. Ethnopharmacol. 2014, 157, 99-104. [CrossRef] [PubMed]

46. Freitas, M.F.; Kinoshita, L.S. Myrsine (Myrsinoideae-Primulaceae) no sudeste e sul do Brasil. Rodriguésia 2015, 66, 167-189. [CrossRef]

47. Calle, J.; Olarte, J.; Pinzon, R.; Ospina, L.F.; Mendoza, M.C.; Orozco, M.J. Alterations in the reproduction of mice induced by rapanone. J. Ethnopharmacol. 2000, 71, 521-525. [CrossRef]

48. Ospina, L.F.; Calle, J.; Arteaga, L.; Pinzón, R.; Alcaraz, M.J.; Payá, M. Inhibition of acute and chronic inflammatory responses by the hydroxybenzoquinonic derivative rapanone. Planta. Med. 2001, 67, 791-795. [CrossRef]

49. Manda, B.R.; Prasad, A.N.; Thatikonda, N.R.; Lacerda, J.R.V.; Barbosa, L.R.; Santos, H.; Romão, W.; Pavan, F.R.; Ribeiro, C.M.; Santos, E.A.; et al. Synthesis, antibacterial and antitubercular evaluation of cardanol and glycerol-based $\beta$-amino alcohol derivatives. J. Braz. Chem. Soc. 2018, 29, 639. [CrossRef]

Sample Availability: Samples of the essential oils are available from the authors.

(C) 2020 by the authors. Licensee MDPI, Basel, Switzerland. This article is an open access article distributed under the terms and conditions of the Creative Commons Attribution (CC BY) license (http://creativecommons.org/licenses/by/4.0/). 